\title{
Speciation of Chromium and Vanadium in Medicinal Plants
}

\author{
Isiaka A. Owolabi, Khakhathi L. Mandiwana* and Nikolai Panichev \\ Department of Chemistry, Tshwane University of Technology, P.O. Box 56208, Arcadia Pretoria, 0007, South Africa.
}

Received 15 October 2015, revised 16 February 2016, accepted 1 March 2016.

\begin{abstract}
In this study, $\mathrm{Cr}(\mathrm{VI})$ and $\mathrm{V}(\mathrm{V})$ were determined in medicinal plants collected from the farm located between two smelters. Chromium(VI) and vanadium(V) were leached from medicinal plants with $0.1 \mathrm{M} \mathrm{Na}_{2} \mathrm{CO}_{3}$ prior their determination by ETAAS. The concentration of $\mathrm{Cr}(\mathrm{VI})$ in medicinal plants varied between $3.1 \pm 0.5 \mu \mathrm{g} \mathrm{g}^{-1}$ and $9.4 \pm 0.2 \mu \mathrm{g} \mathrm{g}^{-1}$ and that of $\mathrm{V}(\mathrm{V})$ ranged from $1.1 \pm 0.08 \mu \mathrm{g} \mathrm{g}^{-1}$ to $17 \pm 1.7 \mu \mathrm{g} \mathrm{g}^{-1}$. It was established that element species taken up by plants do not depend on metal content in soil but is a function of plant properties. Results of the determination of water-soluble (hot water) $\mathrm{Cr}(\mathrm{VI})$ and $\mathrm{V}(\mathrm{V}) \mathrm{concentrations}$ showed that consumption of three cups of tea prepared from medicinal plants from Zizameleni farm is safe since recommended maximum limits is not exceeded through normal consumption of tea infusion.
\end{abstract}

KEYWORDS

Speciation, leaching, medicinal plants, sodium carbonate, electrothermal atomic absorption spectrometry.

\section{Introduction}

Medicinal plants are plants that provide health-promoting characteristics and have curative properties. They are used in the preparation of natural medicinal products and have been used throughout human history. ${ }^{1-2}$ The World Health Organization (WHO) has reported that approximately $75 \%$ of the world's population use medicinal herbs as alternative remedies to modern medicine. ${ }^{3}$ The plant medical applications depends on the traditional experience introduced by local people. ${ }^{4-5}$

The growing awareness among researchers on the importance and uses of medicinal plants in the health care systems has popularized the use of medicinal plants because of the belief that they are safe. ${ }^{6-10}$ The widespread use of herbal medicine comes with the risk of overdoses through inappropriate consumption. ${ }^{11}$

Zizameleni farm $\left(25.5717^{\circ} \mathrm{S}, 27.7959^{\circ} \mathrm{E}\right)$ specializes in the cultivation of medicinal plants. It is located between ferrochrome smelter $\left(25.3938^{\circ} \mathrm{S}, 27.5070^{\circ} \mathrm{E}\right)$ and vanadium smelter $\left(25.3427^{\circ} \mathrm{S}\right.$, $\left.27.5325^{\circ} \mathrm{E}\right)$ and therefore is exposed to smelter emissions. Chromium(VI) is formed during ferrochrome production due to the oxidation of $\mathrm{Cr}(\mathrm{III})$ due to the presence of oxygen $\left(\mathrm{O}_{2}\right)$ at high temperature. ${ }^{12}$ Therefore, $\mathrm{Cr}(\mathrm{VI})$ is released into the atmosphere with smelter emissions.

$2 \mathrm{CR}_{2} \mathrm{O}_{3}(\mathrm{~s})+4 \mathrm{Na}_{2} \mathrm{CO}_{3}(\mathrm{aq})+3 \mathrm{O}_{2}(\mathrm{~s}) \rightarrow 4 \mathrm{NaCrO}_{4}(\mathrm{aq})+4 \mathrm{CO}_{2}(\mathrm{~g})$

Similarly, pentavalent vanadium, $\mathrm{V}(\mathrm{V})$, is emitted to the atmosphere during $\mathrm{V}_{2} \mathrm{O}_{5}$ production by vanadium smelters.

Both $\mathrm{Cr}(\mathrm{VI})$ and $\mathrm{V}(\mathrm{V})$ compounds are toxic and carcinogenic. Smelter emissions to the atmosphere settle in soil and penetrate through deep layers of soil where they are accumulated by plants. Chromium (VI) in the form chromate ions $\left(\mathrm{CrO}_{4}^{2-}\right)$ is easily accumulated by plants because it resembles sulphate ions $\left(\mathrm{SO}_{4}^{2-}\right){ }^{13}$ Similarly, $\mathrm{V}(\mathrm{V})$ in the form of $\mathrm{VO}_{4}{ }^{3-}$ is easily accumulated by plants because $\mathrm{VO}_{4}^{3-}$ ions resemble the most important nutritional $\mathrm{PO}_{4}^{3-}$ ions. ${ }^{14}$

The World Health Organization (WHO) recognized $\mathrm{Cr}(\mathrm{VI})$ as a carcinogenic agent whereas overexposure to $\mathrm{V}(\mathrm{V})$ compounds is linked to kidney, heart and liver damage. ${ }^{15}$ The location of Zizameleni farm between the ferrochrome and vanadium smelters make it a suitable case study to assess the effects of

* To whom correspondence should be addressed. E-mail: mandiwanakl@ tut.ac.za smelter emissions on medicinal plants. Therefore, the objective of this study was to determine the concentration of $\mathrm{Cr}(\mathrm{VI})$ and $\mathrm{V}(\mathrm{V})$ in medicinal plants from Zizameleni farm to verify their suitability for human consumption.

\section{Experimental}

\subsection{Equipment and Reagents}

A Perkin-Elmer Atomic Absorption Spectrometer model AAnalyst 600 which employs Zeeman-effect background correction system was used for all measurements. The spectrometer was equipped with an AS-800 autosampler and the whole system was controlled by means of AA Winlab software with Microsoft Windows 2010 program. Perkin Elmer hollow cathode lamps of vanadium and chromium operating at $318.4 \mathrm{~nm}$ and $357.9 \mathrm{~nm}$ have been used for the determination of $\mathrm{V}$ and $\mathrm{Cr}$, respectively. Transversely heated graphite furnace tubes (THGA) fitted with integrated L'vov platforms (Perkin-Elmer, part N B050-4033) was used as the atomization source.

The stock solutions containing $1000 \mathrm{~g} \mathrm{~L}^{-1} \mathrm{Cr}$ (III) ( $\mathrm{as}^{-\mathrm{CrCl}_{3}}$ ) or $\mathrm{Cr}(\mathrm{VI})\left(\right.$ as $\mathrm{K}_{2} \mathrm{CrO}_{4}$ ) (Merck, South Africa) and $1000 \mathrm{mg} \mathrm{L}^{-1} \mathrm{~V}(\mathrm{~V})$ as $\mathrm{NH}_{4} \mathrm{VO}_{3}$ (Merck, South Africa), were used for the preparation of working standards through serial dilution of the stock solutions. Ultra-pure water with a resistivity of $18.2 \mathrm{M} \Omega \mathrm{cm}^{-1}$ was obtained with a Milli-Q water purification system (Millipore Corporation, U.S.A.), and was used for all dilutions and sample preparations. Argon, $99 \%$ pure (Afrox, South Africa), was used as the protective and purging gas.

\subsection{Quality Assurance}

The analytical results for the determination of chromium and vanadium were validated through the analysis of certified reference materials (CRM 545, MESS-3 and PACS-2). The result of the determination of $\mathrm{Cr}(\mathrm{VI})$ was validated by the analysis of CRM 545 and good agreement between certified $\left(40.2 \pm 0.6 \mu \mathrm{g} \mathrm{g}^{-1}\right)$ and found $\left(39 \pm 1.3 \mu \mathrm{g} \mathrm{g}^{-1}\right)$ values was established. The total content of chromium was determined after complete digestion of the MESS-3 and there was good agreement between the certified value $\left(243 \pm 10 \mu \mathrm{g} \mathrm{g}^{-1}\right)$ and found value $\left(245 \pm 4.2 \mu \mathrm{g} \mathrm{g}^{-1}\right)$. Similarly, for PACS-2, good agreement between the certified value 
$\left(90.7 \pm 4.6 \mu \mathrm{g} \mathrm{g}^{-1}\right)$ and found value $\left(91.3 \pm 2.6 \mu \mathrm{g} \mathrm{g}^{-1}\right)$ was established.

Certified reference materials with certified $V(V)$ content are currently not available. Therefore, the results of $\mathrm{V}(\mathrm{V})$ determination in samples were validated through spiking of samples with $\mathrm{V}(\mathrm{V})$ standard solutions and followed by the determination of percentage recoveries. The $\%$ recoveries of the spiked analytes ranged between $98 \%$ and $105 \%$. The results of total vanadium determination also show good agreement between the found (MESS-3: $234 \pm 10 \mu \mathrm{g} \mathrm{g}^{-1}$; PACS-2: $133 \pm 5 \mu \mathrm{g} \mathrm{g}^{-1}$ ) and certified values (MESS-3: $236 \pm 9 \mu \mathrm{g} \mathrm{g}^{-1}$; PACS-2: $131 \pm 3 \mu \mathrm{g} \mathrm{g}^{-1}$ ).

\subsection{Samples}

Samples were collected from Zizameleni farm $\left(25.5717^{\circ} \mathrm{S}\right.$, $27.7959^{\circ} \mathrm{E}$ ) in August 2013. The farm is located approximately $3 \mathrm{~km}$ from the vanadium smelter (Vametco Alloy, 25.3427 ${ }^{\circ} \mathrm{S}$, $27.5325^{\circ} \mathrm{E}$ ) and $8 \mathrm{~km}$ from the ferrochrome smelter (Hernic ferrochrome, $25.3938^{\circ} \mathrm{S}, 27.5070^{\circ} \mathrm{E}$ ). Twenty species of medicinal plants were collected within $500 \mathrm{~m}^{2}$ area. Soil samples representing the upper soil layer with a thickness of $20 \mathrm{~cm}$ were collected inside the $500 \mathrm{~m}^{2}$ where medicinal plants are planted. Medicinal plants were washed with ultrapure water. All samples were air dried at room temperature and ground to a particle size of less than $200 \mu \mathrm{m}$ with an IKA A11 milling system.

\subsection{Leaching of Metal Species from Solid Samples}

Twenty-five millilitres $(25.00 \mathrm{~mL})$ of $0.1 \mathrm{~mol} \mathrm{~L}^{-1} \mathrm{Na}_{2} \mathrm{CO}_{3}$ was added to approximately $0.25 \mathrm{~g}$ powdered sample and the content was boiled for $15 \mathrm{~min}$. The samples were then allowed to cool to room temperature before being transferred to $50 \mathrm{~mL}$ polypropylene tubes. The final volumes of sample solutions were adjusted to $25.00 \mathrm{~mL}$ with ultra-pure water. The samples were filtered through $0.45 \mu \mathrm{m}$ hydrophilic PVDF filter prior the determination of $\mathrm{Cr}(\mathrm{VI})$ or $\mathrm{V}(\mathrm{V})$ by ET-AAS.

\subsection{Determination of Total Metal Concentrations in Soil Samples}

In order to determine the total concentration of chromium and vanadium, complete digestion of samples was carried out. For this purpose, approximately $0.25 \mathrm{~g}$ of soil was first digested in a 10:1 mixture of concentrated $\mathrm{HF}(5 \mathrm{~mL})$ and concentrated $\mathrm{H}_{2} \mathrm{SO}_{4}$ $(0.5 \mathrm{~mL})$, and heated till near dryness. Furthermore, $1 \mathrm{~mL}$ concentrated $\mathrm{HClO}_{4}$ and $2 \mathrm{~mL}$ concentrated $\mathrm{HF}$ were added and again the mixture was heated to near dryness to evaporate excess acids. Finally, $1 \mathrm{~mL}$ concentrated $\mathrm{HClO}_{4}$ was added, and the sample was evaporated until the appearance of white fumes. The residue was then dissolved in $5 \mathrm{~mL}$ of $6 \mathrm{M} \mathrm{HCl}$ and diluted to $25.0 \mathrm{~mL}$ with ultrapure water. The resulting solution was then analyzed by ET-AAS for total $\mathrm{Cr}$ and total $\mathrm{V}$ concentrations.

\subsection{Determination of Total Metal Concentrations in Medicinal Plants}

Approximately $0.25 \mathrm{~g}$ of plant samples were placed in a porcelain crucible. The temperature of the furnace was slowly increased from room temperature to $650{ }^{\circ} \mathrm{C}$ using muffle furnace. The samples were ashed at this temperature until a white or grey residue ash was formed. The ashes were allowed to cool to room temperature, dissolved in $1 \mathrm{~mL}$ of a mixture 1:1 concentrated $\mathrm{HNO}_{3}$ and concentrated $\mathrm{HCl}$, and diluted to $25.00 \mathrm{~mL}$ with ultra-pure water prior the determination of total $\mathrm{Cr}$ and total $\mathrm{V}$ by ET-AAS.

\subsection{Determination of $\mathrm{Cr}(\mathrm{VI})$ and $\mathrm{V}(\mathrm{V})$ in Medicinal Teas}

Approximately $2 \mathrm{~g}$ of samples was transferred into $500 \mathrm{~mL}$ beaker and $200 \mathrm{~mL}$ ultra-pure water was added. The mixture was boiled for $15 \mathrm{~min}$. The sample solutions were allowed to cool to room temperature before diluting to $200 \mathrm{~mL}$. Alternatively, $2 \mathrm{~g}$ sample was soaked in $200 \mathrm{~mL}$ of hot water for $15 \mathrm{~min}$. In order to determine $\mathrm{Cr}(\mathrm{VI})$ and $\mathrm{V}(\mathrm{V})$, the sample solutions were filtered through $0.45 \mu \mathrm{m}$ hydrophillic PVDF filter prior analysis with ET-AAS. The total $\mathrm{Cr}$ and $\mathrm{V}$ concentrations that is available after boiling medicinal plants in water was determined by analyzing the prepared tea without filtration.

\section{Results and Discussion}

\subsection{Results of the Determination of $\mathrm{Cr}$ and $\mathrm{V}$ in Soil}

The separation of $\mathrm{Cr}(\mathrm{VI})$ from $\mathrm{Cr}(\mathrm{III})$ during leaching is accomplished because $\mathrm{Cr}(\mathrm{VI})$ exist as insoluble $\mathrm{Cr}$ compounds in solid, e.g. $\mathrm{CaCrO}_{4}$, and therefore by treating solid samples with solution of $\mathrm{Na}_{2} \mathrm{CO}_{3}, \mathrm{Cr}(\mathrm{VI})$ is transferred into solution as $\mathrm{Na}_{2} \mathrm{CrO}_{4}$. That way, $\mathrm{Cr}(\mathrm{VI})$ as $\mathrm{Na}_{2} \mathrm{CrO}_{4}$ will pass through the filter and $\mathrm{Cr}(\mathrm{III})$ will remain in the precipitates as $\mathrm{Cr}(\mathrm{OH})_{3}$.

$$
\mathrm{CaCrO}_{4}(\mathrm{~s})+\mathrm{Na}_{2} \mathrm{CO}_{3}(\mathrm{aq}) \rightarrow \mathrm{CO}_{3}(\mathrm{~s})+\mathrm{Na}_{2} \mathrm{CrO}_{4}(\mathrm{aq})
$$

Because $\mathrm{V}(\mathrm{V})$ and $\mathrm{Cr}(\mathrm{VI})$ have similar chemical properties, both of them can be separated from $\mathrm{V}(\mathrm{IV})$ and $\mathrm{Cr}(\mathrm{III})$ compounds, respectively, by treatment with a solution of $\mathrm{Na}_{2} \mathrm{CO}_{3}$.

$$
\mathrm{Ca}_{3}\left(\mathrm{VO}_{4}\right)_{2}(\mathrm{~s})+3 \mathrm{Na}_{2} \mathrm{CO}_{3}(\mathrm{aq}) \rightarrow 3 \mathrm{CaCO}_{3}(\mathrm{~s})+2 \mathrm{Na}_{3} \mathrm{VO}_{4}(\mathrm{aq})
$$

Table 1 summarizes results for the determination of $\mathrm{Cr}(\mathrm{VI})$ and $\mathrm{V}(\mathrm{V})$ concentration in soil. It was found that the concentration of $\mathrm{Cr}(\mathrm{VI})$ in soil ranged between $4.0 \pm 0.2 \mu \mathrm{g} \mathrm{g}^{-1}$ and $10 \pm$ $0.8 \mu \mathrm{g} \mathrm{g}^{-1}$ and that of $\mathrm{V}(\mathrm{V})$ ranged between $11 \pm 0.5 \mu \mathrm{g} \mathrm{g}^{-1}$ and $45 \pm 2.0 \mu \mathrm{g} \mathrm{g}^{-1}$.

The correlation curve between $\mathrm{Cr}(\mathrm{VI})$ and total $\mathrm{Cr}$ in soil was plotted as a function of their concentrations. The correlation curve was linear $\left(R^{2}=0.9999\right)$ indicating that $\mathrm{Cr}(\mathrm{VI})$ and total $\mathrm{Cr}$ originated from the same source as their concentrations increases together (Fig. 1a). Similar results were observed for vanadium (Fig. 1b). Therefore, the differences in concentration of $\mathrm{Cr}(\mathrm{VI})$ and total $\mathrm{Cr}$ or $\mathrm{V}(\mathrm{V})$ and total $\mathrm{V}$ in medicinal plants as compared to that in soil depend on individual plant properties.

\subsection{Results for the Determination of $\mathrm{Cr}$ and $\mathrm{V}$ in Medicinal Plants}

The concentration of $\mathrm{Cr}(\mathrm{VI})$ in medicinal plants varied from $3.1 \pm 0.2 \mu \mathrm{g} \mathrm{g}^{-1}$ to $9.4 \pm 0.6 \mu \mathrm{g} \mathrm{g}^{-1}$ and that of total Cr were in the range between $65 \pm 5 \mu \mathrm{g} \mathrm{g}^{-1}$ and $368 \pm 20 \mu \mathrm{g} \mathrm{g}^{-1}$. The highest $\mathrm{Cr}(\mathrm{VI})$ concentrations were found in Capsicum annuum and Artemisia afra species. The results also showed that Echinacea purpurea has lower uptake of $\mathrm{Cr}(\mathrm{VI})\left(3.1 \pm 0.1 \mu \mathrm{g} \mathrm{g}^{-1}\right)$ but in contrast accumulated high level of total chromium $\left(104 \pm 9 \mu \mathrm{g} \mathrm{g}^{-1}\right)$. This study also showed that Nepeta cataria $\left(9.4 \pm 0.6 \mu \mathrm{g} \mathrm{g}^{-1}\right)$ is the plant that accumulate higher levels while Capsicum annuum accummulated

Table 1 Results for the determination of $\mathrm{Cr}$ and $\mathrm{V}$ in soil $(n=6)$.

\begin{tabular}{lrrrr}
\hline & $\begin{array}{c}\text { [Cr(VI)] } \\
/ \mu \mathrm{g} \mathrm{g}^{-1}\end{array}$ & \multicolumn{1}{c}{$\begin{array}{c}\text { Total }[\mathrm{Cr}] \\
/ \mu \mathrm{g} \mathrm{g}^{-1}\end{array}$} & $\begin{array}{c}{[\mathrm{V}(\mathrm{V})],} \\
/ \mu \mathrm{g} \mathrm{g}^{-1}\end{array}$ & \multicolumn{1}{c}{$\begin{array}{c}\text { Total }[\mathrm{V}] \\
/ \mu \mathrm{g} \mathrm{g}^{-1}\end{array}$} \\
\hline Soil 1 & $10 \pm 0.8$ & $1723 \pm 86$ & $19 \pm 1.0$ & $802 \pm 25$ \\
Soil 2 & $4.0 \pm 0.2$ & $714 \pm 35$ & $11 \pm 0.5$ & $525 \pm 14$ \\
Soil 3 & $6.2 \pm 0.4$ & $1021 \pm 41$ & $45 \pm 2.0$ & $1775 \pm 90$ \\
Soil 4 & $8.0 \pm 0.6$ & $1400 \pm 70$ & $32 \pm 1.5$ & $1300 \pm 40$ \\
Means & $7.1 \pm 0.5$ & $1215 \pm 58$ & $27 \pm 1.3$ & $1001 \pm 40$ \\
\hline
\end{tabular}

Mean $\pm t_{0.05} \times \frac{s}{\sqrt{n}}$

$\bar{x} \pm t_{0.05} \times s / \sqrt{n}$ 

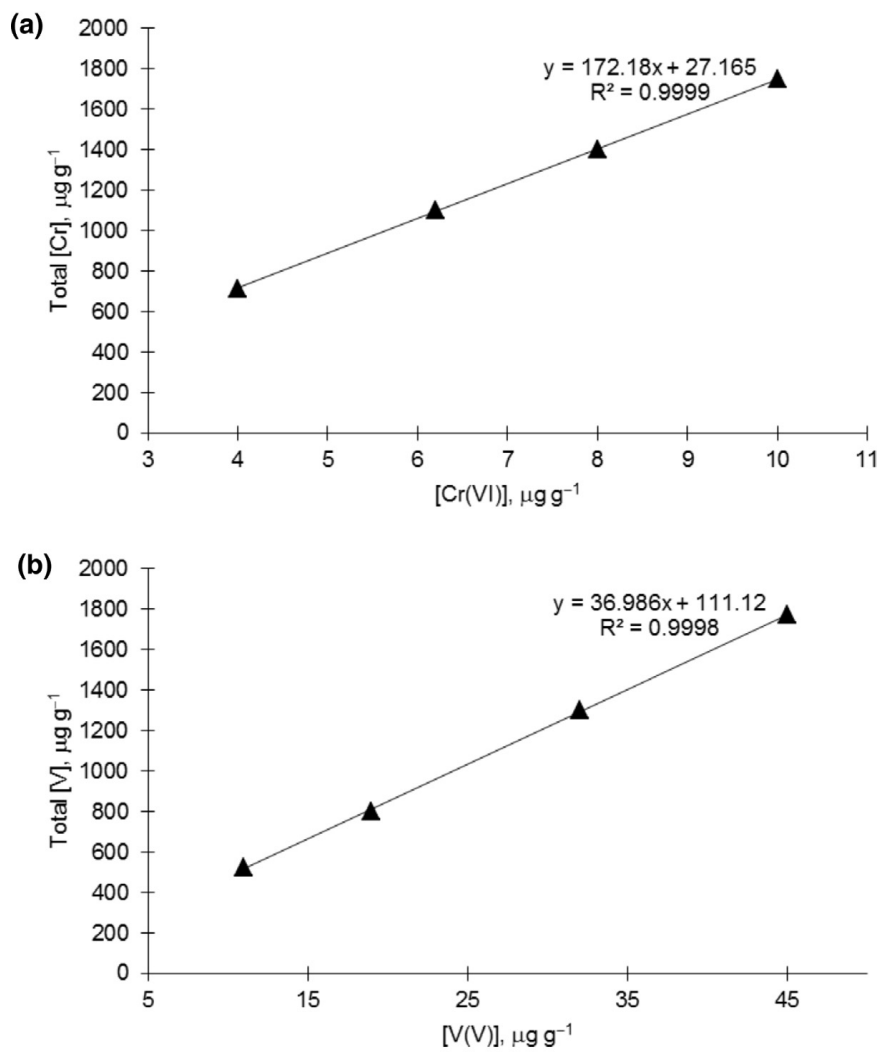

Figure 1 Correlation curve between concentration of metal species and total metal concentration: (a), chromium; (b), vanadium.

higher levels of total $\mathrm{Cr}\left(368 \pm 20 \mu \mathrm{g} \mathrm{g}^{-1}\right)$ (Table 2). The concentration of $\mathrm{Cr}(\mathrm{VI})$ in Rosmarinus officinalis in this study $(4.1 \pm 0.2 \mu \mathrm{g}$ $\left.\mathrm{g}^{-1}\right)$ was 8 times higher than those collected from different herbalists in Hatay region $\left(0.49 \pm 0.01 \mu \mathrm{g} \mathrm{g}^{-1}\right)$ in Turkey. ${ }^{16}$ The results of vanadium determination in medicinal plants indicated that low amount of vanadium is present as $\mathrm{V}(\mathrm{V})$ species.
The results also shows that $\mathrm{V}(\mathrm{V})$ content is only a fraction of the total vanadium content. The concentrations of $\mathrm{V}(\mathrm{V})$ leached from plants in Artemisia afra, Nepeta cataria and Salvia officinalis were equal at $95 \%$ level of confidence but in contrast have different total vanadium concentration of $66 \pm 3.0 \mu \mathrm{g} \mathrm{g}^{-1}$, $104 \pm 8.0 \mu \mathrm{g} \mathrm{g}^{-1}$ and $439 \pm 2.0 \mu \mathrm{g} \mathrm{g}^{-1}$, respectively. It was also found that Bidens pilosa $\left(27 \pm 1.6 \mu \mathrm{g} \mathrm{g}^{-1}\right)$ accumulate the highest levels of V(V) while Salvia officinalis (439 $\left.\pm 2.0 \mu \mathrm{g} \mathrm{g}^{-1}\right)$ accumulated the highest total vanadium (Table 3 ). It was not possible to compare results of vanadium determination with those in literature due to limited data available and differences in medicinal plants species. ${ }^{17}$

\subsection{Results for the Determination of $\mathrm{Cr}(\mathrm{VI})$ and $\mathrm{V}(\mathrm{V})$ in Medicinal Teas}

According to the World Health Organization (WHO), the maximum recommended concentration of $\mathrm{Cr}(\mathrm{VI})$ that should be consumed is $50 \mu \mathrm{g}$ day $^{-1}$ and that of $\mathrm{V}(\mathrm{V})$ is $60 \mu \mathrm{g} \mathrm{day}^{-1}$. $^{15,18-19}$ Therefore, to assess whether $\mathrm{Cr}(\mathrm{VI})$ in medicinal plants from Zizameleni does not exceed these limits, one medicinal cup of tea was prepared as normally recommended on most medicinal packages. Two grams ( $2 \mathrm{~g}$ ) of medicinal plants (leaves or roots) were boiled in $200 \mathrm{~mL}$ ultra-pure water or soaked in $200 \mathrm{~mL}$ of hot ultra-pure water for $15 \mathrm{~min}$ prior the determination of analytes. To determine $\mathrm{Cr}(\mathrm{VI})$ and $\mathrm{V}(\mathrm{V})$ that could be consumed per cup of medicinal tea, the samples were filtered through $0.45 \mu \mathrm{m}$ hydrophilic filter before analysis. The results of the determination of $\mathrm{Cr}(\mathrm{VI})$ in medicinal plants showed that hot water leach a small fraction of $\mathrm{Cr}(\mathrm{VI})$ and $\mathrm{V}(\mathrm{V})$. Approximately $0.1 \mu \mathrm{g} \mathrm{g}^{-1}$ was found in each gram medicinal plant tea soaked implying that a person could consume a maximum of $0.6 \mu \mathrm{g}$ day $^{-1}$ of $\mathrm{Cr}(\mathrm{VI})$ by drinking a maximum of three cups of medicinal tea per day (Table 4). Therefore, it can be concluded that a person can only exceed the recommended daily $\mathrm{Cr}(\mathrm{VI})$ limit by drinking at least 83 cups of medicinal teas. Similarly, the maximum of $3.6 \mu \mathrm{g}$ day $^{-1}$ of $\mathrm{V}(\mathrm{V})$ could be consumed per day by drinking three cups of medicinal tea (Table 4). Therefore, it would require drinking at least 17 cups of medicinal tea to exceed the maximum

Table 2 Results of the determination of $\mathrm{Cr}(\mathrm{VI})$ and total chromium in medicinal plants $\left(n=6\right.$, Mean $\left.\pm t_{0.05} \times \frac{s}{\sqrt{n}}\right)$.

\begin{tabular}{|c|c|c|c|c|c|}
\hline Common name & Botanical name & Part used & {$[\mathrm{Cr}(\mathrm{VI})] / \mu \mathrm{g} \mathrm{g}^{-1}$} & Total $[\mathrm{Cr}] / \mu \mathrm{g} \mathrm{g}^{-1}$ & $\% \mathrm{Cr}(\mathrm{VI})$ \\
\hline African potato & Hypoxis hemerocallidea & Seed & $8.3 \pm 0.4$ & $178 \pm 10$ & 4.7 \\
\hline Aloe vera & Aloe barbadensis miller & Leaves & $4.5 \pm 0.2$ & $67 \pm 4$ & 6.7 \\
\hline Beetroot & Beta vulgaris & Root & $4.4 \pm 0.2$ & $106 \pm 4$ & 4.2 \\
\hline Blackjack & Bidens pilosa & Leaves & $5.9 \pm 0.3$ & $105 \pm 8$ & 5.6 \\
\hline Buffalo thorn & Ziziphus mucronata & Leaves & $4.6 \pm 0.4$ & $65 \pm 5$ & 7.1 \\
\hline Catmint & Nepeta cataria & Leaves & $9.4 \pm 0.6$ & $73 \pm 6$ & 13 \\
\hline Chillies & Capsicum annuum & Seed & $9.2 \pm 0.4$ & $368 \pm 20$ & 2.5 \\
\hline Coneflower & Echinacea purpurea & Leaves and flower & $3.1 \pm 0.2$ & $104 \pm 9$ & 2.9 \\
\hline Garden sage & Salvia officinalis & Leaves & $8.3 \pm 0.5$ & $91 \pm 7$ & 9.1 \\
\hline Golden rods & Solidago virgaurea & Leaves and flower & $5.0 \pm 0.2$ & $86 \pm 5$ & 5.8 \\
\hline Karee & Rhus lancea & Leaves & $5.0 \pm 0.1$ & $188 \pm 10$ & 2.7 \\
\hline Kie apple & Dovyalis caffra & Seed & $5.6 \pm 0.3$ & $109 \pm 9$ & 5.1 \\
\hline Lemon grass & Cymbopogon & Leaves & $6.0 \pm 0.4$ & $144 \pm 17$ & 4.2 \\
\hline Lemon verbena & Aloysia citrodora & Leaves & $9.1 \pm 0.6$ & $223 \pm 20$ & 4.1 \\
\hline Pepper-bark tree & Warburgia salutaris & Leaves & $7.2 \pm 0.3$ & $97 \pm 7$ & 7.4 \\
\hline Rosemary & Rosmarinus officinalis & Leaves & $4.1 \pm 0.1$ & $152 \pm 10$ & 2.7 \\
\hline Stinging nettle & Urtica dioca & Leaves & $8.0 \pm 0.4$ & $186 \pm 24$ & 4.3 \\
\hline Thyme & Thymus vulgaris & Leaves & $6.4 \pm 0.3$ & $84 \pm 7$ & 7.6 \\
\hline Tomato & Solanum lycopersicum & Seed & $8.3 \pm 0.4$ & $228 \pm 15$ & 3.6 \\
\hline Wild wormwood & Artemisia afra & Leaves & $8.2 \pm 0.6$ & $229 \pm 25$ & 3.6 \\
\hline
\end{tabular}


Table 3 Results of determination for $\mathrm{V}(\mathrm{V})$ and total vanadium in plants $\left(n=6\right.$; Mean $\left.\pm t_{0.05} \times \frac{s}{\sqrt{n}}\right)$.

\begin{tabular}{|c|c|c|c|c|c|}
\hline Common name & Botanical name & Part used & {$[\mathrm{V}(\mathrm{V})] / \mu \mathrm{g} \mathrm{g}^{-1}$} & Total $[\mathrm{V}] / \mu \mathrm{g} \mathrm{g}^{-1}$ & $\% \mathrm{~V}(\mathrm{~V})$ \\
\hline African potato & Hypoxis hemerocallidea & Seed & $17 \pm 0.8$ & $112 \pm 10$ & 16 \\
\hline Aloe vera & Aloe barbadensis miller & Leaves & $6.9 \pm 0.5$ & $61 \pm 0.8$ & 11 \\
\hline Beetroot & Beta vulgaris & Root & $2.3 \pm 0.2$ & $46 \pm 0.5$ & 5 \\
\hline Blackjack & Bidens pilosa & Leaves & $27 \pm 2.0$ & $89 \pm 5.0$ & 30 \\
\hline Buffalo thorn & Ziziphus mucronata & Leaves & $17 \pm 1.0$ & $122 \pm 6.0$ & 14 \\
\hline Catmint & Nepeta cataria & Leaves & $16 \pm 0.8$ & $104 \pm 8.0$ & 15 \\
\hline Chillies & Capsicum annuum & Seed & $5.0 \pm 0.3$ & $146 \pm 10$ & 3.4 \\
\hline Coneflower & Echinacea purpurea & Leaves \& flower & $12.4 \pm 1.0$ & $44 \pm 0.8$ & 27 \\
\hline Garden sage & Salvia officinalis & Leaves & $16 \pm 0.8$ & $439 \pm 20$ & 4 \\
\hline Golden rods & Solidago virgaurea & Leaves \& flower & $4.0 \pm 0.4$ & $35 \pm 2.0$ & 11 \\
\hline Karee & Rhus lancea & Leaves & $17 \pm 1.7$ & $84 \pm 4.0$ & 20 \\
\hline Kie apple & Dovyalis caffra & Seed & $4.4 \pm 0.5$ & $19 \pm 1.0$ & 23 \\
\hline Lemon grass & Cymbopogon & Leaves & $6.4 \pm 0.4$ & $22 \pm 1.5$ & 29 \\
\hline Lemon verbena & Aloysia citrodora & Leaves & $15 \pm 0.8$ & $63 \pm 2.5$ & 24 \\
\hline Pepper bark & Warburgia salutaris & Leaves & $1.1 \pm 0.8$ & $25 \pm 1.0$ & 4.4 \\
\hline Rosemary & Rosmarinus officinalis & Leaves & $1.4 \pm 0.1$ & $33 \pm 1.5$ & 4.2 \\
\hline Stinging nettle & Urtica dioca & Leaves & $4.5 \pm 0.5$ & $18 \pm 0.8$ & 25 \\
\hline Thyme & Thymus vulgaris & Leaves & $12 \pm 0.6$ & $44 \pm 1.0$ & 27 \\
\hline Tomato & Solanum lycopersicum & Seed & $13 \pm 1.0$ & $51 \pm 2.0$ & 21 \\
\hline Wild wormwood & Artemisia afra & Leaves & $16 \pm 0.8$ & $66 \pm 3.0$ & 24 \\
\hline
\end{tabular}

Table 4 Results of the determination of $\mathrm{Cr}(\mathrm{VI})$ and $\mathrm{V}(\mathrm{V})$ in medicinal teas $(n=6)$.

\begin{tabular}{llll}
\hline Common name & Botanical name & $\begin{array}{c}{[\mathrm{Cr}(\mathrm{VI})]} \\
/ \mu \mathrm{g} \mathrm{day}\end{array}$ & $\begin{array}{c}{ }^{-1} \\
{[\mu \mathrm{V}(\mathrm{VI})]}\end{array}$ \\
\hline African potato & \\
Aloe vera & Hypoxis hemerocallidea & $0.1 \pm 0.01$ & $0.2 \pm 0.01$ \\
Beetroot & Aloe barbadensis miller & $0.1 \pm 0.01$ & $0.3 \pm 0.01$ \\
Blackjack & Beta vulgaris & $0.1 \pm 0.01$ & $0.1 \pm 0.01$ \\
Buffalo thorn & Bidens pilosa & $0.1 \pm 0.01$ & $0.1 \pm 0.01$ \\
Catmint & Ziziphus mucronata & $0.1 \pm 0.01$ & $0.2 \pm 0.01$ \\
Chillies & Nepeta cataria & $0.1 \pm 0.01$ & $0.1 \pm 0.01$ \\
Coneflower & Capsicum annuum & $0.1 \pm 0.01$ & $0.1 \pm 0.01$ \\
Garden sage & Echinacea purpurea & $0.1 \pm 0.01$ & $0.2 \pm 0.01$ \\
Golden rods & Salvia officinalis & $0.1 \pm 0.01$ & $0.2 \pm 0.01$ \\
Karee & Solidago virgaurea & $0.1 \pm 0.01$ & $0.1 \pm 0.01$ \\
Kie apple & Rhus lancea & $0.1 \pm 0.01$ & $0.1 \pm 0.01$ \\
Lemon grass & Dovyalis caffra & $0.1 \pm 0.01$ & $0.1 \pm 0.01$ \\
Lemon verbena & Cymbopogon & $0.1 \pm 0.01$ & $0.4 \pm 0.01$ \\
Pepper bark & Aloysia citrodora & $0.1 \pm 0.01$ & $0.2 \pm 0.01$ \\
Rosemary & Warburgia salutaris & $0.1 \pm 0.01$ & $0.2 \pm 0.01$ \\
Stinging nettle & Rosmarinus officinalis & $0.1 \pm 0.01$ & $0.1 \pm 0.01$ \\
Thyme & Urtica dioca & $0.1 \pm 0.01$ & $0.3 \pm 0.01$ \\
Tomato & Thymus vulgaris & $0.1 \pm 0.01$ & $0.1 \pm 0.01$ \\
Wild wormwood & Solanum lycopersicum & $0.1 \pm 0.01$ & $0.6 \pm 0.01$ \\
\hline & Artemisia afra & $0.1 \pm 0.01$ & $0.1 \pm 0.01$ \\
\hline
\end{tabular}

recommended daily limit of $\mathrm{V}(\mathrm{V})$. It is practically impossible to exceed these limits and therefore, teas prepared from medicinal plants from Zizameleni farm are safe for human consumption.

\section{Conclusions}

Analysis of medicinal plants collected in the farm between $\mathrm{Cr}$ and $\mathrm{V}$ smelters showed that $\mathrm{Cr}(\mathrm{VI})$ and $\mathrm{V}(\mathrm{V})$ contents accumulated by plants depends on individual plant species and is not a function of metal species concentration in soil. It was also found that an individual cannot exceed the recommended maximum daily limits of $\mathrm{Cr}(\mathrm{VI})$ and $\mathrm{V}(\mathrm{V})$ by consuming three cups of medicinal tea per day.

\section{References}

1 M.J. Jordán, J. Castillo, S. Bañón, C. Martínez-Conesa and J.A. Sotomayor, Relevance of the carnosic acid/carnosol ratio for the level of rosemary diterpene transfer and for improving lamb meat antioxidant status, Food Chem., 2014, 151, 212-218.

2 M.M. Iwu, Handbook of African Medicinal Plants, 2nd edn., CRC Press, Boca Raton, 2014

3 I. Ujváry, Pest control agents from natural products, in Hayes' Handbook of Pesticide Toxicology, (R. Krieger, ed.), 3rd edn., Academic Press, New York, 2010, pp. 119-229.

4 M. Leonti, The future is written: impact of scripts on the cognition, selection, knowledge and transmission of medicinal plant use and its implications for ethnobotanyand ethnopharmacology, J. Ethnopharmacol., 2011, 134, 542-555.

5 B. Kamsu-Foguem, G. Diallo and C. Foguem, Conceptual graph based knowledge representation for supporting reasoning in African traditional medicine, Eng. Appl. Artif. Intel., 2013, 26, 1348-1365.

6 A. Maroyi, An ethnobotanical survey of medicinal plants used by the people in Nhema communal area, Zimbabwe, J. Ethnopharmacol., 2011, 136, 347-354

7 S.S. Ningthoujam, A.D. Talukdar, K.S. Potsangbam and M.D. Choudhury, Challenges in developing medicinal plant databases for sharing ethnopharmacological knowledge, J. Ethnopharmacol., 2012, 141, 9-32.

8 G.O. Barney, Environment projections, in The Global 2000 Report to the President of the U.S., (G.O. Barney, ed.), Pergamon, 2013, 13, 227-449.

9 E. Bignante and N. Tecco, Is indigenous health knowledge converging to herbalism? Healing practices among the Meru and the Maasai of the Ngarenyanyuki ward, Northern Tanzania, Geoforum, 2013, 48, 177-186.

10 A. Filipiak-Szok, M. Kurzawa and E. Szlyk, Determination of toxic metals by ICP-MS in Asiatic and European medicinal plants and dietary supplements, J. Trace Elem. Med. Biol., 2015, 30, 54-58.

11 S. Mcwhorter, C. Read, G. Ordaz and N. Stetson, Materials-based hydrogen storage: Attributes for near-term, early market PEM fuel cells, Curr. Opin. Solid State Mater. Sci., 2011, 15, 29-38.

12 J.M. Pacyna and J.O. Nriagu, Atmospheric emissions of chromium from natural and anthropogenic sources, in Chromium in the Natural 
and Human Environment, (J.O. Nriagu and E. Nieboer, eds.), John Wiley \& Sons, Toronto, 1988, pp. 105-124.

13 G. Svehla, Vogel's Qualitative Inorganic Analysis, 7th edn., Longman Singapore Publishers, Singapore, 1996.

14 R.R. Moskalyk and A.M. Alfantazi, Processing of vanadium: a review, Miner. Eng., 2003, 16, 793-805.

15 WHO, World Health Organization, Safety evaluation of certain food additives and contaminants. WHO Food Additives Series: Safety evaluation of certain food additives and contaminants. Prepared by the Seventy-fourth meeting of the Joint FAO/WHO Expert Committee on Food Additives (JECFA), Geneva, 2012, 65: 81-86.

16 S. Sungu, Y. Kilboz and M.M. Atan, Determination of chromium species in various medicinal plants consumed in Hatay region in Turkey, Int. J. Food Prop., 2013, 16, 1711-1716.

17 D.S. Antal, C.A. Dehelean, C.M. Canciu and M. Anke, Vanadium in medicinal plants: new data on the occurrence of an element both essential and toxic to plants and men, Analele Universității din Oradea, Fascicula Biologie, XVI/2, pp. 5-10. 2009.

$18 \mathrm{M}$. Jović and S. Stanković, Human exposure to trace metals and possible public health risks via consumption of mussels Mytilus galloprovincialis from the Adriatic coastal area. Food Chem. Toxicol., 2014, 8: 241-251.

19 Y. Qian, FJ. Gallagher, H. Feng, M. Wu and Q. Zhu, Q., Vanadium uptake and translocation in dominant plant species on an urban coastal brown field site, Sci. Total Environ., 2014, 4, 696-704. 